\title{
34. PETROLEUM-GENERATING POTENTIAL OF SEDIMENTS FROM THE EASTERN MEDITERRANEAN AND BLACK SEAS
}

\author{
J. W. Kendrick, A. Hood, and J. R. Castaño, \\ Shell Development Company, Houston, Texas
}

\begin{abstract}
The petroleum-generating potential of late Cenozoic sediments from the eastern Mediterranean and Black seas was evaluated in terms of their organic richness and thermal history. The results of the study indicate that sediments in both basins contain sufficient amounts of thermally reactive organic matter to be considered potential, or future, petroleum source rocks. None of the samples. however, has been buried deeply enough to reach the levels of organic metamorphism at which significant petroleum generation occurs. The ratios of effective carbon to organic carbon and the visual kerogen studies indicate that the organic-rich samples contain greater proportions of lipid and primary humic organic matter than the organic-lean sediments, which contain greater proportions of thermally inert organic matter.
\end{abstract}

\section{INTRODUCTION}

Several authors have discussed the occurrence of organic-rich sediments in the Mediterranean (Olausson, 1961; Ryan, 1971; Nesteroff, 1973) and Black seas (Degens and Ross, 1974). The Black Sea, in particular, has attracted considerable attention as a basin in which organic-rich sediments are currently being deposited. Because such types of deposits are possible sources of petroleum, we obtained several sediment samples from the eastern Mediterranean and Black seas for the purpose of evaluating their petroleum-generating potential. Our objectives were to determine whether the sediments in either region contained enough thermally reactive organic matter for significant petroleum generation and whether such sediments had already been exposed to sufficiently high subsurface temperatures for the thermal conversion of kerogen to petroleum. In addition, we used organic richness data and visual kerogen analyses to characterize the types of organic matter in the sediments.

To evaluate the organic richness of the sediment samples, we determined both their organic carbon $\left(\mathrm{C}_{\mathrm{org}}\right)$ and effective carbon $\left(\mathrm{C}_{\text {eff }}\right)$ contents. Organic carbon, or acid-insoluble carbon, represents the total amount of organic matter in the sediment, and it is determined by measuring the carbon dioxide evolved during combustion of an acid-treated sample. Effective carbon, on the other hand, reflects the portion of organic carbon which is thermally convertible to petroleum. As estimates of effective carbon, we used two laboratory pyrolysis precedures. One method, pyrolysis-fluorescence (PF), is a rapid means of evaluating a sediment's petroleum-generating potential, by measuring (in arbitrary PF units) the amount of fluorescing bitumen generated on heating. PF values in rocks can range from zero to several thousand units.
The second method, pyrolysis-FID (P-FID), provides a measure of the hydrocarbons and hydrocarbon-like compounds produced by heating the sample from $25^{\circ}$ to $750^{\circ} \mathrm{C}$. The effective carbon content is computed as $85 \%$ of the pyrolysis hydrocarbon $\left(300^{\circ}-650^{\circ} \mathrm{C}\right)$ yield, and it neglects hydrocarbons which are distilled from the sample at lower temperatures.

The conversion of kerogen to petroleum is a temperature-dependent reaction, and the effects of organic metamorphism can be observed as changes in the chemical and physical properties of the kerogen. As a measure of the level of organic metamorphism (LOM; Hood et al., 1975), we determined the reflectance (in oil) of vitrinite, a coal maceral which is disseminated in many sediments. As shown in Figure 1, vitrinite reflectance is applicable over the wide range of coal rank and LOM in which oil and gas are formed.

Hood et al. (1976) have provided a more complete description of the analytical methods used in this report.

\section{RESULTS AND DISCUSSION}

The samples used in this study come from the locations shown in Figure 2. While most of the sediments were collected during Legs $42 \mathrm{~A}$ and $42 \mathrm{~B}$ of the Deep Sea Drilling Project (DSDP), supplementary samples from DSDP Leg 13 and cruise AII-49 of Woods Hole Oceanographic Institution are included. Core AII-40-1474K, in particular, provides a record of Holocene Black Sea sediments, which was incompletely recovered by DSDP. Because only 5 of the 29 samples are from the Mediterranean Sea, the emphasis of this study is on the Black Sea sediments.

\section{Organic Richness}

Numerous values of organic carbon content have been suggested as minimum requirements for petroleoum source rocks. The diversity of opinion 


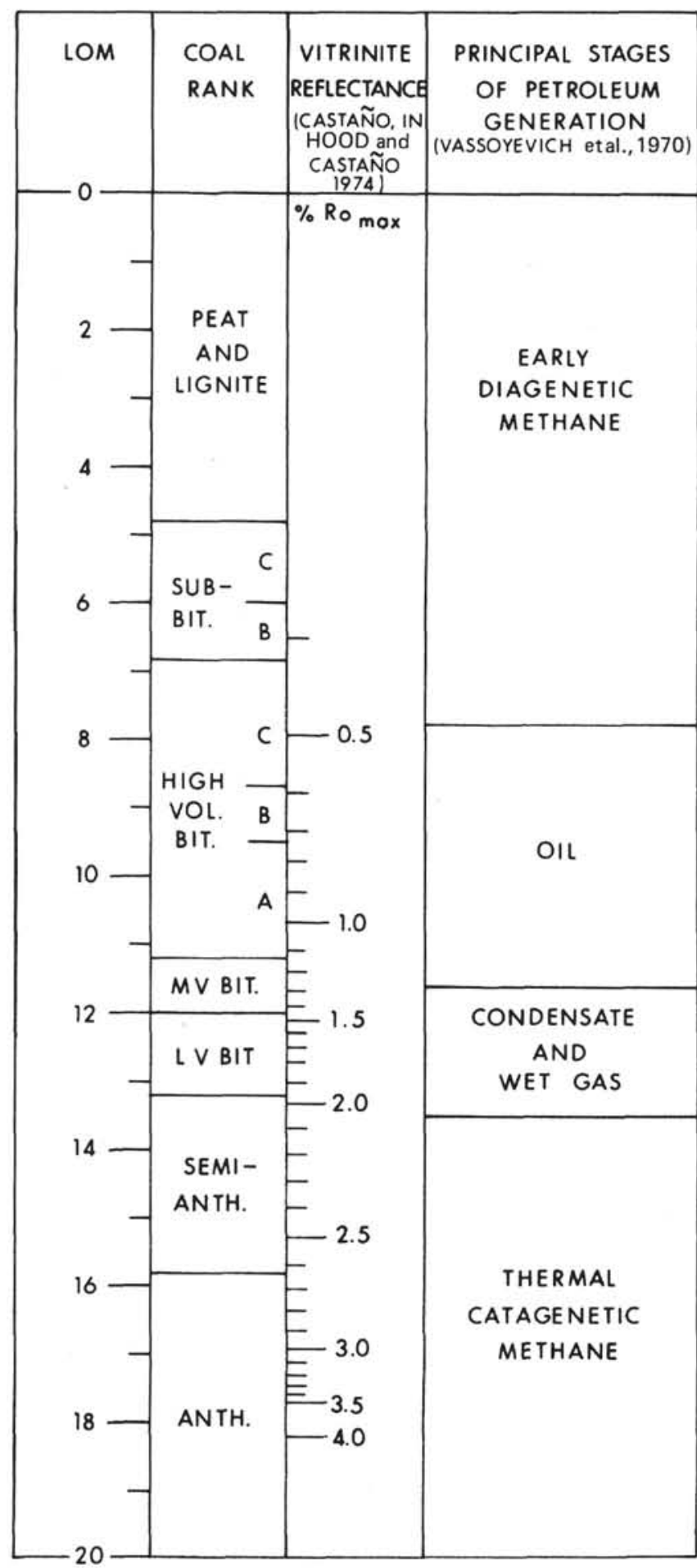

Figure 1. Scale relating coal rank, vitrinite reflectance, and petroleum generation to the level of organic metamorphism (LOM), after Hood and Castano (1974) and Hood et al. (1975).

reflects the difficulty of attributing petroleum within a sedimentary basin to strata of a specific richness. Additionally, estimates of minimum carbon content are necessarily arbitrary, as the amount of petroleum generated depends on the type, as well as the quantity, of organic matter in the sediment.

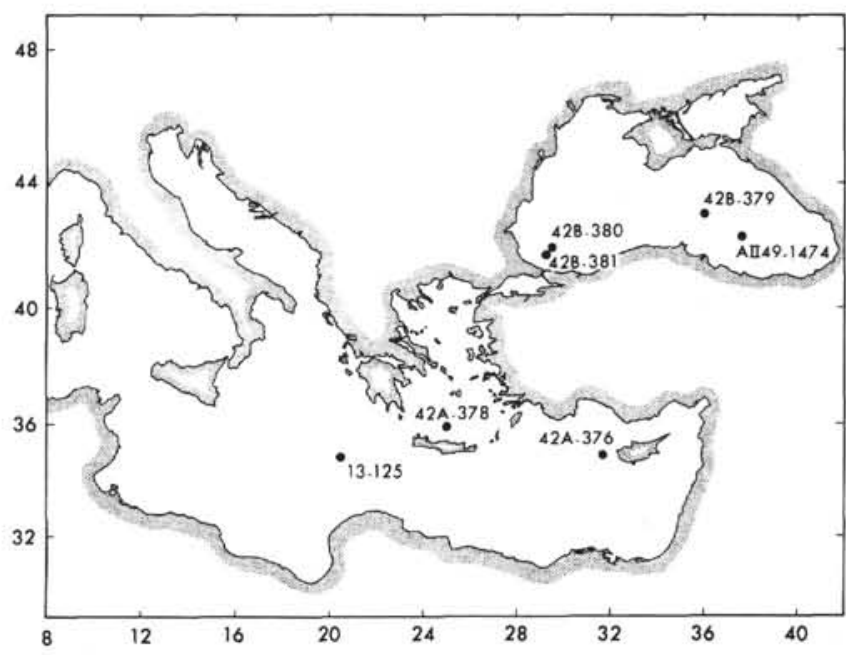

Figure 2. Map of Mediterranean Sea and Black Sea, showing locations from which samples were taken.

Based on organic richness studies of petroliferous and non-petrolifeous basins (Ronov, 1958; Schrayer and Zarella, 1963), we generally regard $1.0 \%$ to $1.5 \%$ $\mathrm{C}_{\text {org }}$ as a minimum requirement for a petroleum source rock. We consider pyrolysis techniques, however, to be more accurate indicators of a sediment's petroleumgenerating potential, since they measure directly the petroleum-like compounds generated during heating. In this regard, we believe a sample must have a PF greater than 10 or a pyrolysis hydrocarbon yield greater than $0.30 \%\left(0.26 \% \mathrm{C}_{\text {eff }}\right)$ before it can be considered a potential, or future, source rock.

The sediments from the Mediterranean and Black seas display a wide spectrum of organic richness values (Table 1), ranging from 0.24 to $15.5 \% \mathrm{C}_{\text {org }}$ and from 0.01 to $6.18 \% \mathrm{C}_{\text {eff }}$. According to the criteria above, several of the Black Sea samples, as well as one sample from the Mediterranean, can be considered potential source rocks of petroleum. For some samples, however, organic carbon and effective carbon give conflicting indications of petroleum-generating potential. Some samples (e.g., Sample 381-54-0, 3-14 cm) contain more than $2.0 \% \mathrm{C}_{\text {org }}$ but less than $0.2 \% \mathrm{C}_{\text {eff }}$, while another (Sample $380-51-5,3-11 \mathrm{~cm}$ ) had barely $1 \% \mathrm{C}_{\text {org }}$ and yet contained $0.4 \% \mathrm{C}_{\text {eff }}$. Such comparisons illustrate the problems of evaluating petroleum-generating potential by using organic carbon data alone.

The potential source rocks in the Black Sea are primarily Miocene and Pliocene in age. Surprisingly, very few Quaternary sediments, except the surface sediments from Core AII49-1474, contain enough organic matter to be considered potential source rocks. Sedimentological and paleontological studies of Black Sea sediments in the site summary chapters of this volume suggest that water conditions were brackish to marine during deposition of the organic-rich sediments. The association of potential source rocks with brackish-marine conditions implies that the process by which abundant organic matter was preserved in the sediments were similar to those today. Presently, saline waters from the Mediterranean Sea flow into the Black Sea and sink beneath the less saline surface waters. The 
TABLE 1

Organic Richness

\begin{tabular}{|c|c|c|c|c|c|c|}
\hline $\begin{array}{c}\text { Sample } \\
\text { (Interval in } \mathrm{cm} \text { ) }\end{array}$ & $\begin{array}{l}\text { Depth } \\
\text { (m) }\end{array}$ & Age & $\% \mathrm{C}_{\text {org }}$ & PF & $\begin{array}{c}\% \mathrm{HC} \\
\text { From P-FID } \\
\left(300-650^{\circ} \mathrm{C}\right)\end{array}$ & $\% \mathrm{C}_{\text {eff }}$ \\
\hline \multicolumn{7}{|l|}{ Mediterranean Sea } \\
\hline $\begin{array}{l}13-125-3-4,40 \\
42 A-376-9-2,130-135 \\
42 A-378-1 A-4,130-134 \\
42 A-378-6-2,130-135 \\
42 A-378-3 A-3,130-134\end{array}$ & $\begin{array}{r}22 \\
77 \\
52 \\
144 \\
297\end{array}$ & $\begin{array}{l}\text { Pleistocene } \\
\text { U. Miocene } \\
\text { Pleistocene } \\
\text { Pleistocene } \\
\text { L. Pliocene }\end{array}$ & $\begin{array}{l}15.5 \\
0.30 \\
0.19 \\
0.22 \\
0.22\end{array}$ & $\begin{array}{r}195 \\
4 \\
3 \\
1 \\
5\end{array}$ & $\begin{array}{l}7.21 \\
0.01 \\
0.01 \\
0.02 \\
0.02\end{array}$ & $\begin{array}{l}6.13 \\
0.01 \\
0.01 \\
0.02 \\
0.02\end{array}$ \\
\hline \multicolumn{7}{|l|}{ Black Sea } \\
\hline $\begin{array}{l}\text { A } 1149-1474 \mathrm{~K}, 9-10 \\
\text { A1149-1474K, 40-42 } \\
\text { A1149-1474K, 174-177 } \\
\text { 42B-379-25A-4, 5-8 } \\
\text { 42B-379-30A-3, 105-110 } \\
\text { 42B-379-57A-6, 88-91 }\end{array}$ & $\begin{array}{r}0 \\
0 \\
2 \\
230 \\
277 \\
528\end{array}$ & $\begin{array}{l}\text { Holocene } \\
\text { Holocene } \\
\text { Quaternary } \\
\text { Quaternary } \\
\text { Quaternary } \\
\text { Pliocene/ } \\
\text { Quaternary }\end{array}$ & $\begin{array}{l}2.75 \\
9.6 \\
0.34 \\
0.78 \\
0.55 \\
0.89\end{array}$ & $\begin{array}{r}170 \\
675 \\
1 \\
2 \\
4 \\
5\end{array}$ & $\begin{array}{l}1.57 \\
7.27 \\
0.03 \\
0.04 \\
0.02 \\
0.07\end{array}$ & $\begin{array}{l}1.38 \\
6.18 \\
0.02 \\
0.03 \\
0.02 \\
0.06\end{array}$ \\
\hline $\begin{array}{l}\text { 42B-380-0-3, 103-130 } \\
\text { 42B-380-21A-3, } 72-78\end{array}$ & $\begin{array}{r}4 \\
526\end{array}$ & $\begin{array}{l}\text { Quaternary } \\
\text { Pliocene/ } \\
\text { Quaternary }\end{array}$ & $\begin{array}{l}0.23 \\
0.68\end{array}$ & $\begin{array}{l}6 \\
5\end{array}$ & $\begin{array}{l}0.01 \\
0.04\end{array}$ & $\begin{array}{l}0.01 \\
0.03\end{array}$ \\
\hline $\begin{array}{l}42 \mathrm{~B}-380-45 \mathrm{~A}-2,43-51 \\
42 \mathrm{~B}-380-46 \mathrm{~A}-6,35-44 \\
42 \mathrm{~B}-380-48 \mathrm{~A}-0,18-25 \\
42 \mathrm{~B}-380-51 \mathrm{~A}-5,3-11 \\
42 \mathrm{~B}-380-55 \mathrm{~A}-2,50-57 \\
42 \mathrm{~B}-380-64 \mathrm{~A}-5,38-45\end{array}$ & $\begin{array}{l}743 \\
750 \\
770 \\
804 \\
838 \\
928\end{array}$ & $\begin{array}{l}\text { Pliocene } \\
\text { Pliocene } \\
\text { Pliocene } \\
\text { Pliocene } \\
\text { Pliocene } \\
\text { Miocene/ }\end{array}$ & $\begin{array}{l}1.97 \\
2.77 \\
1.80 \\
0.98 \\
1.54 \\
2.17\end{array}$ & $\begin{array}{r}72 \\
165 \\
18 \\
8 \\
1 \\
34\end{array}$ & $\begin{array}{l}0.67 \\
1.06 \\
0.60 \\
0.40 \\
0.47 \\
1.13\end{array}$ & $\begin{array}{l}0.57 \\
0.90 \\
0.51 \\
0.34 \\
0.40 \\
0.96\end{array}$ \\
\hline $42 \mathrm{~B}-380-76 \mathrm{~A}-3,77-84$ & 1039 & $\begin{array}{c}\text { Pliocene } \\
\text { Miocene/ } \\
\text { Pliocene }\end{array}$ & 1.12 & 0 & 0.12 & 0.10 \\
\hline $42 B-380-78 A-6,26-30$ & 1062 & $\begin{array}{l}\text { Miocene/ } \\
\text { Pliocene }\end{array}$ & 1.82 & 16 & 0.48 & 0.41 \\
\hline 42B-381-9-0, 70-77 & 77 & Quaternary & 0.67 & 1 & 0.05 & 0.04 \\
\hline $42 \mathrm{~B}-381-13-2,35-43$ & 116 & Quaternary & 0.84 & 1 & 0.08 & 0.07 \\
\hline 42B-381-23-6, $123-129$ & 208 & Pliocene & 1.38 & 1 & 0.22 & 0.19 \\
\hline $42 \mathrm{~B}-381-26-1,30-36$ & 228 & Pliocene & 1.67 & 7 & 0.32 & 0.27 \\
\hline $42 \mathrm{~B}-381-33-5,25-30$ & 301 & Pliocene & 1.16 & 8 & 0.51 & 0.44 \\
\hline $42 \mathrm{~B}-381-37-3,28-34$ & 336 & Pliocene & 8.03 & 450 & 5.23 & 4.45 \\
\hline 42B-381-54-0, 3-14 & 494 & $\begin{array}{l}\text { Miocene/ } \\
\text { Pliocene }\end{array}$ & 2.48 & 1 & 0.21 & 0.18 \\
\hline 42B-381-54-5, 84-90 & 501 & $\begin{array}{l}\text { Miocene/ } \\
\text { Pliocene }\end{array}$ & 2.12 & 3 & 0.24 & 0.21 \\
\hline
\end{tabular}

halocline which is developed between these waters of differing salinity impedes the supply of dissolved oxygen to deeper waters, allowing more organic matter on the sea floor to escape oxidation and decomposition.

Various authors (Ryan, 1971; Nesteroff, 1973) also regard the periodic stagnation of the Mediterranean Sea to have been caused by the development of strong haloclines. Sample 13-125-3-4, $40 \mathrm{~cm}$ represents one of several sapropelites deposited in the Mediterranean during Plio-Pleistocene time. The samples from Leg $42 \mathrm{~A}$ all display very low values of organic carbon, reflecting the sharp differences in organic richness and depositional environment between the sapropelites and the intervening sediments

\section{Level of Organic Metamorphism (LOM)}

As illustrated by the histograms of vitrinite reflectance $\left(R_{0}\right)$ in Figure 3 , the distribution of reflectance values varies considerably for different samples. Sample 381-23-6, 123-129 cm exhibits a very narrow distribution of reflectance values, much like a humic coal. More commonly, however, samples from the Mediterranean and Black seas display a very broad distribution of vitrinite reflectance values similar to the histogram for Sample 42A-378-3A-3, 130-134 cm. The occurrence of broad reflectance distributions implies that some vitrinite has been either partially oxidized or recycled from older sedimentary units with a prior thermal history. Because the reflectance values of primary and reworked, or secondary, vitrinite often overlap, it is commonly difficult to distinguish the two. Samples containing secondary vitrinite, however, will yield estimates of LOM which are too high if based on the entire population of reflectance values.

The results of the vitrinite reflectance measurements are summarized in Table 2. For each sample, an "X" value is listed, which indicates the range and mean of all reflectance measurements made on the sample. For some samples, an " $\mathrm{A}$ " value is also given, which indicates those measurements interpreted to be primary vitrinite. "A" values and LOM's have been determined only for those samples in which the primary vitrinite can readily be distinguished from the histogram of vitrinite reflectance values. 

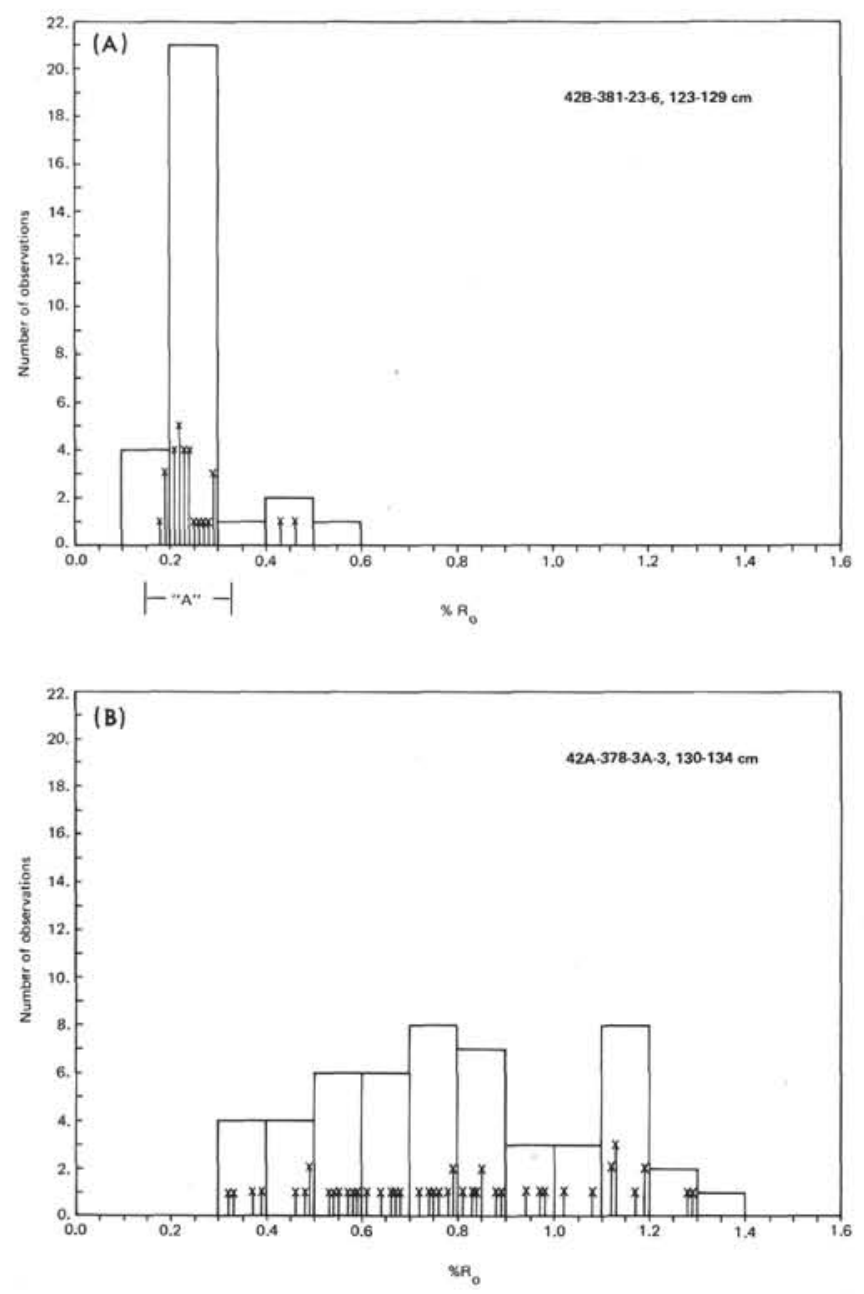

Figure 3. Histograms of vitrinite reflectance for samples containing, (A) mostly primary vitrinite (42B-381-23-6, $123-129 \mathrm{~cm}) ;(B)$ mostly reworked vitrinite (42A-378$3 A-3,130-134 \mathrm{~cm})$. " $A$ " denotes the interpreted range of primary vitrinite values.

The histograms of vitrinite reflectance for several samples from the Black Sea exhibit strong modes which are indicative of primary vitrinite. Such samples were used to trace the mean value of $R_{0}$ for primary vitrinite as a function of depth in Figure 4 . The histograms of several additional samples are more complex, displaying modes which cannot be identified as primary vitrinite without comparison to other samples.

From Figure 4 it appears that the mean values of vitrinite reflectance for the Black Sea sediments lie between $0.25 \%$ and $0.35 \%$ and remain almost constant with depth at each site. These values of vitrinite reflectance correspond to coal ranks of lignite to subbituminous C and to LOM's less than seven, indicating that these sediments have not been buried deeply enough to reach the LOM ( 7.8, Hood et al., 1975) at which significant oil generation begins.

The vitrinite reflectance measurements of sediments from the Meditteranean do not provide such reliable estimates of LOM. The samples display wide ranges of reflectance values (Table 2; Figure $3[\mathrm{~B}]$ ) which make it difficult to infer the reflectance of primary vitrinite that may be present in the samples. Considering the LOM's of sediments at similar burial depths (less than $300 \mathrm{~m}$ ) in the Black Sea, it is unlikely that the Mediterranean sediments have reached LOM's of seven or more.

Subsurface temperature measurements made during Leg 42 (Erickson, in press; Erickson, this volume) also suggest that none of the sediments have reached the oil generation stage. Work by Philippi (1965) and La Plante (1974) indicates that oil generation in late Tertiary sediments occurs at depths where the temperature exceeds $96^{\circ}$ to $115^{\circ} \mathrm{C}$. In the DSDP cores, temperatures at the depths where vitrinite reflectance measurements were made do not exceed $46^{\circ} \mathrm{C}$ (Table 2).

Consequently, despite the high contents of organic matter in the sediments of the Mediterranean and Black seas, both vitrinite reflectance measurements and subsurface temperature determinations indicate that such sediments can be considered only as potential, or future, source rocks of petroleum.

\section{Types of Organic Matter}

During the measurement of vitrinite reflectance, visual estimates of the types of organic matter were made according to the classification shown in Table 3. Liptinite and amorphous kerogen represent lipid-rich organic matter which is either structured (spores, algae, etc.) or structureless, respectively. Land plant, or humic, material is classified as primary vitrinite. Reworked humic matter, however, is considered to be inertinite, together with thermally inert macerals like fusinite and micrinite.

The estimates of organic type in Table 3 indicate that the organic matter in many sediments is predominantly humic or reworked humic material. Increasing amounts of lipid-rich material tend to occur in sediments with higher contents of organic matter, reflecting perhaps better conditions for organic preservation. The lipidrich organic matter at Site 380 and Core AII49-1474 is primarily amorphous kerogen, whereas liptinite (i.e., spores) predominates in the lipid-rich fraction of sediments at Site 381 .

The different organic types observable in the visual kerogen studies are also manifested in the organicrichness data. The samples with abundant inertinite often have effective carbon contents which are less than $10 \%$ of the organic carbon values. As the amount of lipid-rich material in the sediment increases, so does the ratio of $\mathrm{C}_{\text {eff }}$ to $\mathrm{C}_{\text {org }}$, exceeding $50 \%$ for samples like Sample 381-37-3, 28-34 cm.

\section{ACKNOWLEDGMENTS}

The authors wish to thank Woods Hole Oceanographic Institution (sponsored by National Science Foundation Grant GA-1659) and the Deep Sea Drilling Project for providing the samples used in this study, as well as Shell Development Company for granting permission to conduct this work.

\section{REFERENCES}

Degens, E.T. and Ross, D.A. (Eds.), 1974. The Black Sea-Geology, chemistry, and biology: Am. Assoc. Petrol. Geol. Mem. 20, p. 1-633. 
TABLE 2

Vitrinite Reflectance and Level of Organic Metamorphism

\begin{tabular}{|c|c|c|c|c|c|c|c|}
\hline $\begin{array}{c}\text { Sample } \\
\text { (Interval in } \mathrm{cm} \text { ) }\end{array}$ & $\begin{array}{l}\text { Depth } \\
\text { (m) }\end{array}$ & $-{ }^{a}$ & $\begin{array}{c}\text { No. of } \\
\text { Observations }\end{array}$ & Range of $\% R_{0}$ & Mean $\% R_{o}{ }^{b}$ & LOM $^{\mathrm{c}}$ & $\begin{array}{c}\text { Subsurface } \\
\text { Temperature } \\
\left({ }^{\circ} \mathrm{C}\right)\end{array}$ \\
\hline \multicolumn{8}{|l|}{ Mediterranean Sea } \\
\hline $\begin{array}{l}42 \mathrm{~A}-376-9-2,130-135 \\
42 \mathrm{~A}-378-1 \mathrm{~A}-4,130-134 \\
42 \mathrm{~A}-378-6-2,130-135 \\
42 \mathrm{~A}-378-3 \mathrm{~A}-3,130-134\end{array}$ & $\begin{array}{r}77 \\
52 \\
144 \\
297\end{array}$ & $\begin{array}{l}X \\
X \\
X \\
X\end{array}$ & $\begin{array}{l}54 \\
60 \\
52 \\
52\end{array}$ & $\begin{array}{l}0.21-1.10 \\
0.35-2.22 \\
0.19-1.56 \\
-.32-1.30\end{array}$ & $\begin{array}{l}0.61 \pm 0.07 \\
0.76 \pm 0.09 \\
0.84 \pm 0.09 \\
0.81 \pm 0.08\end{array}$ & $\begin{array}{l}\text { N.D. } \\
\text { N.D. } \\
\text { N.D. } \\
\text { N.D. }\end{array}$ & 15 \\
\hline \multicolumn{8}{|l|}{ Black Sea } \\
\hline A1149-1474K, 9-10 & 0 & $\mathrm{X}$ & 10 & $0.11-0.70$ & $0.38 \pm 0.17$ & N.D. & \\
\hline A $1149-1474 \mathrm{~K}, 40-42$ & 0 & $\begin{array}{l}\mathrm{A} \\
\mathrm{X}\end{array}$ & $\begin{array}{l}13 \\
23\end{array}$ & $\begin{array}{l}0.11-0.31 \\
0.11-0.74\end{array}$ & $\begin{array}{l}0.20 \pm 0.04 \\
0.33 \pm 0.08\end{array}$ & & \\
\hline A1149-1474K, 174-177 & 2 & $\hat{x}$ & 48 & $0.31-0.99$ & $0.65 \pm 0.05$ & N.D. & \\
\hline $42 \mathrm{~B}-379-25 \mathrm{~A}-4,5-8$ & 230 & $\begin{array}{l}\mathrm{A} \\
\mathrm{X}\end{array}$ & $\begin{array}{l}46 \\
57\end{array}$ & $\begin{array}{l}0.28-0.49 \\
0.28-0.71\end{array}$ & $\begin{array}{l}035 \pm 0.01 \\
0.40 \pm 0.03\end{array}$ & $\begin{array}{l}<7 \\
\text { N.D. }\end{array}$ & \\
\hline $42 \mathrm{~B}-379-30 \mathrm{~A}-3,105-110$ & 277 & $\mathrm{~A}$ & 57 & $0.20-0.49$ & $0.35 \pm 0.02$ & $<7$ & \\
\hline $42 \mathrm{~B}-379-57 \mathrm{~A}-6,88-91$ & 528 & $\begin{array}{l}\mathrm{X} \\
\mathrm{X}\end{array}$ & $\begin{array}{l}67 \\
59\end{array}$ & $\begin{array}{l}0.20-0.65 \\
0.20-0.80\end{array}$ & $\begin{array}{l}0.39 \pm 0.03 \\
0.44 \pm 0.05\end{array}$ & $\begin{array}{l}\text { N.D. } \\
\text { N.D. }\end{array}$ & 28 \\
\hline $42 \mathrm{~B}-380-0-3,103-130$ & 4 & $\mathrm{x}$ & 44 & $0.13-0.78$ & $0.36 \pm 0.05$ & N.D. & \\
\hline $42 \mathrm{~B}-380-21 \mathrm{~A}-3,72-78$ & 526 & $\mathrm{X}$ & 51 & $0.22-0.99$ & $0.59 \pm 0.06$ & N.D. & \\
\hline $42 \mathrm{~B}-380-45 \mathrm{~A}-2,43-51$ & 743 & $\mathrm{X}$ & 50 & $0.16-0.92$ & $0.42 \pm 0.06$ & N.D. & \\
\hline \multirow[t]{2}{*}{$42 \mathrm{~B}-380-46 \mathrm{~A}-6,35-44$} & 758 & A & 21 & $0.15-0.35$ & $0.25 \pm 0.03$ & $<7$ & \\
\hline & & $\mathrm{X}$ & 34 & $0.15-0.85$ & $0.39 \pm 0.07$ & N.D. & \\
\hline $42 \mathrm{~B}-380-48 \mathrm{~A}-0,18-25$ & 770 & $\mathrm{X}$ & 52 & $0.17-0.92$ & $0.50 \pm 0.06$ & N.D. & \\
\hline $42 \mathrm{~B}-380-51 \mathrm{~A}-5,3-11$ & 804 & $\mathrm{X}$ & 52 & $0.20-0.97$ & $0.48 \pm 0.05$ & N.D. & \\
\hline $42 \mathrm{~B}-380-55 \mathrm{~A}-2,50-57$ & 838 & $\mathrm{X}$ & 49 & $0.12-1.02$ & $0.59 \pm 0.07$ & N.D. & \\
\hline $42 \mathrm{~B}-380-64 \mathrm{~A}-5,38-45$ & 928 & $\mathrm{X}$ & 51 & $0.17-1.02$ & $0.54 \pm 0.06$ & N.D. & \\
\hline \multirow[t]{2}{*}{$42 \mathrm{~B}-380-76 \mathrm{~A}-3,77-84$} & 1039 & A & 43 & $0.21-0.39$ & $0.27 \pm 0.01$ & $<7$ & \\
\hline & & $\mathrm{X}$ & 51 & $0.21-0.74$ & $0.31 \pm 0.04$ & N.D. & \\
\hline \multirow[t]{2}{*}{$42 \mathrm{~B}-380-78 \mathrm{~A}-6,26-30$} & 1062 & A & 48 & $0.18-0.37$ & $0.25 \pm 0.01$ & $<$ & 46 \\
\hline & & $\mathrm{x}$ & 50 & $0.18-0.74$ & $0.26 \pm 0.03$ & N.D. & \\
\hline 42B-381-9-0, 70-77 & 77 & $\mathrm{X}$ & 35 & $0.26-0.77$ & $0.49 \pm 0.04$ & N.D. & \\
\hline $42 \mathrm{~B}-381-13-2,35-43$ & 116 & $\mathrm{X}$ & 26 & $0.27-0.73$ & $0.46 \pm 0.06$ & N.D. & \\
\hline \multirow[t]{2}{*}{$42 \mathrm{~B}-381-23-6,123-129$} & 208 & A & 33 & $0.18-0.03$ & $0.23 \pm 0.01$ & $<7$ & \\
\hline & & $\mathrm{X}$ & 36 & $0.18-0.50$ & $0.25 \pm 0.03$ & N.D. & \\
\hline \multirow[t]{2}{*}{ 42B-381-26-1, 30-36 } & 228 & A & 27 & $0.15-0.36$ & $0.26 \pm 0.0 \mathrm{~s}$ & $<7$ & \\
\hline & & $\mathrm{X}$ & 29 & $0.15-0.42$ & $0.27 \pm 0.02$ & N.D. & \\
\hline $42 \mathrm{~B}-381-33-5,25-30$ & 301 & $\mathrm{X}$ & 18 & $0.17-0.45$ & $0.33 \pm 0.05$ & N.D. & \\
\hline $42 \mathrm{~B}-381-37-3,28-34$ & 336 & $\mathrm{X}$ & 28 & $0.18-0.58$ & $0.33 \pm 0.04$ & N.D. & \\
\hline \multirow[t]{2}{*}{$42 \mathrm{~B}-381-54-0,3-14$} & 494 & A & 74 & $0.16-0.34$ & $0.24 \pm 0.01$ & $<7$ & \\
\hline & & $\mathrm{X}$ & 74 & $0.16-0.34$ & $0.24 \pm 0.01$ & $<7$ & \\
\hline \multirow[t]{2}{*}{ 42B-381-54-5, 84-90 } & 501 & A & 54 & $0.21-0.44$ & $0.28 \pm 0.02$ & $<7$ & 36 \\
\hline & & $\mathrm{X}$ & 54 & $0.20-0.44$ & $0.28 \pm 0.02$ & $<7$ & \\
\hline
\end{tabular}

a " $\mathrm{X}$ " represents the range of all vitrinite reflectance measurements; " $\mathrm{A}$ " represents the range of reflectance measurements interpreted to be primary vitrinite.

$\mathrm{b}_{\%} \mathrm{R}_{\mathrm{o}} \pm 95 \%$ confidence limit.

${ }^{c}$ All $R_{0}$ values less than $0.43 \%$ are assigned LOM $<7$ because of the difficulty of resolving the LOM $0-7$ range by means of vitrinite reflectance. $R_{0}$ values $\geqslant 0.43 \%$ are converted to LOM on the basis of Castano's R - LOM relationship (Hood and Castano, 1974).

${ }^{\mathrm{d}}$ Subsurface temperature data are from Erickson (in press) and Erickson (this volume). 
J. W. KENDRICK, A. HOOD, J. R. CASTANO

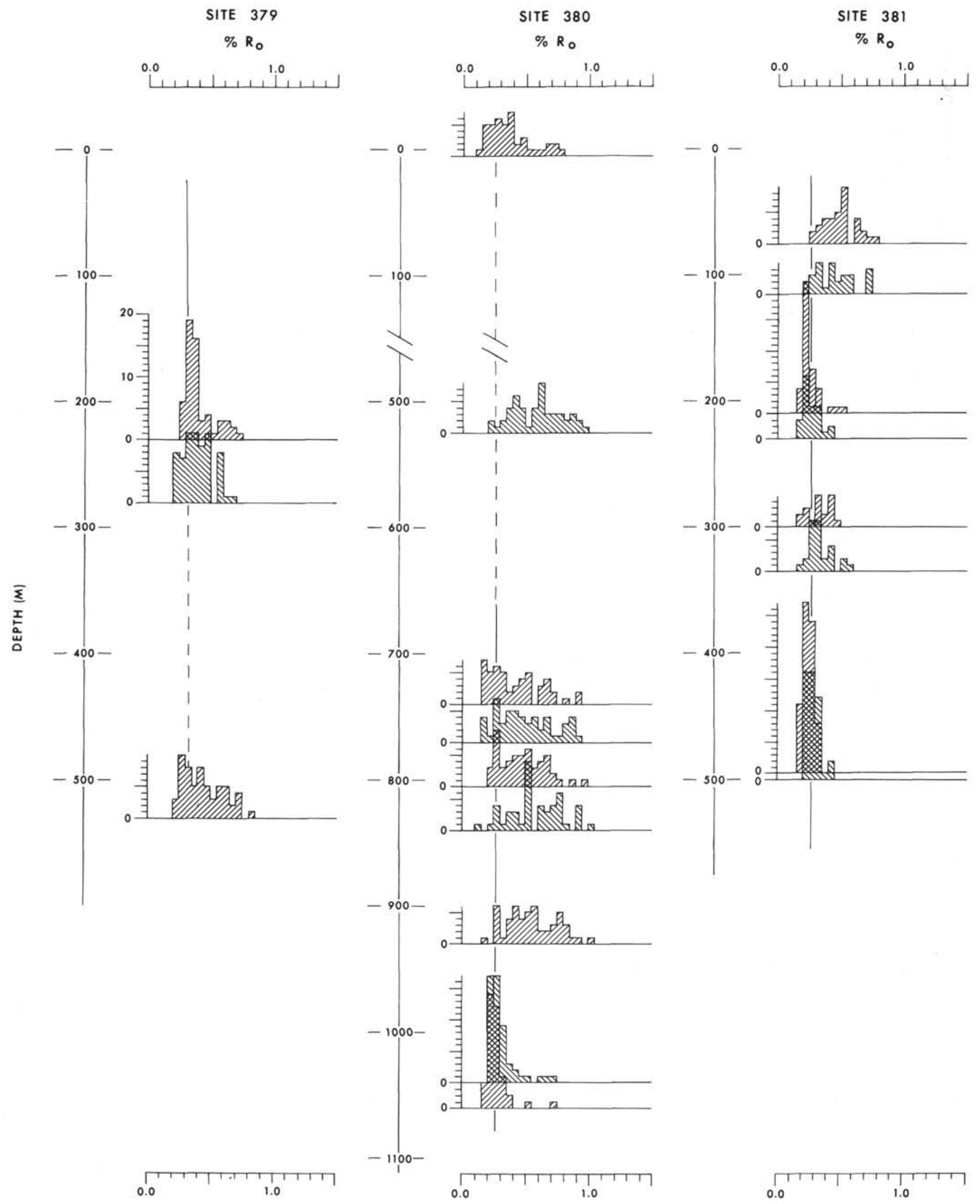

Figure 4. Histograms of vitrinite reflectance $\left(R_{O}\right)$ as a function of depth below the sea floor at Sites 379, 380, and 381 in the Black Sea. The solid and dashed lines trace the mean value of $R_{O}$ for primary vitrinite. 
TABLE 3

Relative Abundance of Types of Organic Matter by Visual Kerogen Analysis ${ }^{\mathrm{a}}$

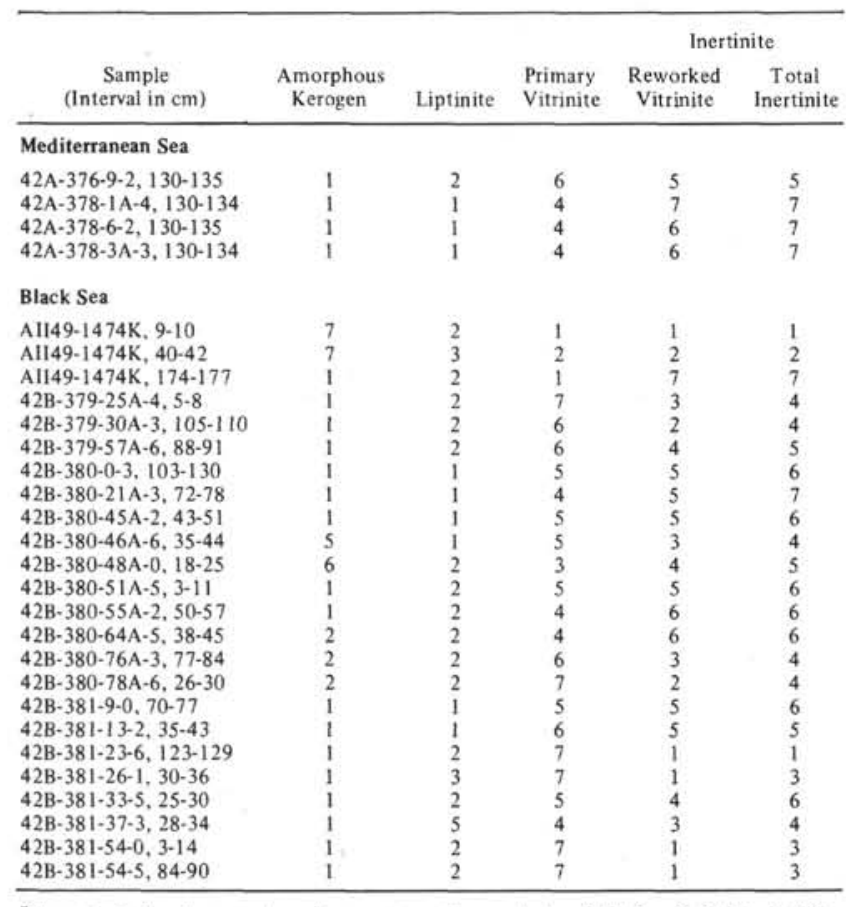

${ }^{a}$ Numerical abundance scale and percentages (by area) $: 1=0-1 \% ; 2=2-5 \% ; 3=6-10 \%$; $4=11-25 \% ; 5=26-50 \% ; 6=51-75 \% ; 7=76-100 \%$.

Erickson, A.E., in press. Heat flow measurements in the Mediterranean Sea. In Hsü, K.J., Montadert, L., et al., Initial Reports of the Deep Sea Drilling Project, Volume 42A: Washington (U.S. Government Printing Office).

Hood, A. and Castaño, J.R., 1974. Organic metamorphism: Its relationship to petroleum generation and application to studies of authigenic minerals: U.N. ESCAP, CCOP Tech. Bull., v. 8, p. 85-118.
Hood, A., Gutjahr, C.C.M., and Heacock, R.L., 1975. Organic metamorphism and generation of petroleum: Am. Assoc. Petrol. Geol. Bull., v. 59, p. 986-996.

Hood, A., Castaño, J. R., and Kendrick, J. W., 1976. Petroleum-generating potential and thermal history of DSDP Leg 38 sediments. In Talwani, M., Udintsev, G., et al., Initial Reports of the Deep Sea Drilling Project, Volume 38: Washington (U.S. Government Printing Office), p. 801-803.

La Plante, R.E., 1974. Hydrocarbon generation in Gulf Coast Tertiary sediments. Am. Assoc. Petrol. Geol. Bull., v. 58, p. 1281-1289.

Nesteroff, W.D., 1973. Petrography and Mineralogy of sapropels. In Ryan, W.B.F., Hsü, K.J., et al., Initial Reports of the Deep Sea Drilling Project, Volume 13: Washington (U.S. Government Printing Office), 713-720.

Olausson, E., 1961. Studies of deep sea cores. Sediment cores from the Mediterranean Sea and the Red Sea: Rep. Swedish Deep-Sea Exped., 1947-1948, v. 8, p. 335-392.

Philippi, G.T., 1965. On the depth, time and mechanism of petroleum generation; Geochim. Cosmochim. Acta, v. 29, p. 1021-1049.

Ronov, A.B., 1958. Organic carbon in sedimentary rocks (in relation to the presence of petroleum); Geochemistry (a translation of Geokhimiya), No. 5, p. 510-536.

Ryan, W.B.F., 1971. Stratigraphy of Late Quaternary sediments in the eastern Mediterranean. In Stanley, D.J. (Ed.), The Mediterranean Sea: A natural sedimentation laboratory; Stroudsburg, (Dowden, Hutchinson, \& Ross), p. 149-169.

Schrayer, G.J. and Zarella, W.M., 1963. Organic geochemistry of shales - I. Distribution of organic matter in siliceous Mowry Shale of Wyoming: Geochim. Cosmochim. Acta, v. 27, p. 1033-1046.

Vassoyevich, N.D., Korchagina, Yu. I., Lopatin, N.V., and Chernyshev, V.V. 1970. Principle phase of oil formation: Moskov. Univ. Vestnik, No. 6, 3-27 (in Russian); Engl. translation: Internat. Geol. Rev., v. 12, p. 1276-1296. 